\begin{tabular}{cc}
\hline JPPIPA, Vol.2 No.1 2017 \\
Jurnal Penelitian Pendidikan IPA
\end{tabular}

\title{
PEMBELAJARAN INKUIRI TERBIMBING UNTUK MENINGKATKAN KEMAMPUAN BERNALAR SISWA KELAS VI BERBANTUAN MEDIA BUKU POP UP
}

Oleh:

Muhammad Yusuf Arifin ${ }^{1}$, Tjandra Kirana ${ }^{2}$, Wahono Widodo ${ }^{3}$

${ }^{1}$ Prodi Pendidikan Dasar, Pascasarjana, Universitas Negeri Surabaya 60231, Indonesia

${ }^{2}$ Prodi Pendidikan Sains, Pascasarjana, Universitas Negeri Surabaya 60231, Indonesia

${ }^{3}$ Jurusan IPA, Fakultas MIPA, Universitas Negeri Surabaya, Surabaya 60231, Indonesia.

\begin{abstract}
Abstrak
Kemampuan bernalar yang dimiliki oleh siswa kelas VI SD dapat dikatakan masih rendah dikarenakan pembelajaran yang masih bersifat konvensional atau berpusat pada guru, sehingga penelitian bertujuan mengembangkan perangkat pembelajaran inkuiri terbimbing untuk meningkatkan kemampuan bernalar berbantuan media buku pop up. Rancangan penelitian menggunakan One Group Pretest-Posttest dengan sasaran penelitian pada 47 siswa di SD Islam Surya Buana Malang yang terdiri dari 2 kelas yaitu kelas VI A dan VI B. Hasil penelitian menunjukkan perangkat pembelajaran yang terdiri dari silabus, rencana pelaksanaan pembelajaran (RPP), lembar kegiatan siswa (LKS), dan tes kemampuan bernalar, layak untuk diterapkan berdasarkan tiga kriteria kelayakan. Pertama, valid berdasarkan penilain pakar dengan rata-rata skor 4 pada skala 5. Kedua, praktis dengan keterlaksanaan pembelajaran sebesar $90 \%$ terlaksana dan aktivitas siswa menunjukkan berlangsungnya kegiatan inkuiri terbimbing dalam pembelajaran. Perangkat pembelajaran yang dikembangkan terbukti dapat meningkatkan kemampuan bernalar siswa kelas VI SD, berdasarkan tingkat kemampuan bernalar pada Taksonomi SOLO. Kemampuan bernalar dapat meningkat dari level prastruktural menjadi level multistruktural dengan tingkat kenaikan yang sangat signifikan berdasarkan nilai uji $\mathrm{t}\left(\mathrm{t}_{\text {hitung }}>\mathrm{t}_{\text {tabel }}\right)$. Hasil belajar siswa juga meningkat dengan derajat perbedaan nilai pretes-postes pada kategori sedang berdasarkan analisis $\mathrm{N}$-Gain $(\mathrm{N}-$ Gain $=0,63)$. Respon positif yang diberikan oleh siswa tentang pembelajaran berbasis inkuiri terbimbing berbantuan buku ajar pop up bahwa sangat memudahkan siswa untuk bernalar dan pembelajaran menjadi mudah serta menarik.
\end{abstract}

Kata Kunci : inkuiri terbimbing, pop up, Kemampuan bernalar.

\begin{abstract}
The reasoning ability possessed by sixth grade elementary school students can be said is still low because of learning that is still conventional or teacher-centered, so this research aimed to developing a guided inquiry learning device to improve reasoning ability assisted a pop up book media. This research design used One Group Pretest - Postest which the objective of the study were 47 students of SD Islam Surya Buana Malang which consists of 2 classes of VI A class and VI B class. The result of this study showed that learning device consists of a syllabus, learning plan (RPP), student activity sheet (LKS), and test reasoning ability, deserves to be applied based on the three criteria of expedience. First, a valid assessment by experts with an average score of 4 on a scale of 5. Second, the practical enforceability of the study is $90 \%$ done and the student activity indicates ongoing activities guided inquiry learning. Learning device that was modified showed that it could improve students reasoning ability in the sixth grade students base on level of SOLO Taxonomy. The reasoning ability could improve from prastructural level become multistructural level with significant increased based on the value of $t$ test $(t>$ ttable). The students learning outcomes being increased on pretest and postest in medium category based on $N$-Gain analysis $(N$-Gain=0,63). Besides, positive responses given by the students about guided inquiry learning with pop up book media which made them interest and easier to improve their reasoning ability.
\end{abstract}

Keywords: guided inquiry, pop up, reasoning ability.

(C) 2017 Universitas Negeri Surabaya

${ }^{1}$ Alamat Korespondensi:

Prodi Pendidikan Dasar, Pascasarjana,

p-ISSN: 2527-7537

Universitas Negeri Surabaya 60231, Indonesia

e-ISSN: 2549-2209

Email: arifinmuhammadyusuf@gmail.com 


\section{PENDAHULUAN}

Pendidikan merupakan suatu proses yang dapat memberikan kepada seseorang suatu pengalaman, pengetahuan, dan keterampilan untuk mendapatkan kehidupan yang lebih baik. Ketiga hal tersebut dapat diterima melalui rasa ingin tahu yang timbul dari diri seseorang, sehingga menimbulkan keinginan untuk berbuat sesuatu untuk mendapatkan pemahaman yang lebih mendalam tentang segala sesuatu yang ada di alam. Salah satu usaha yang dapat dilakukan agar siswa sekolah dasar (SD) dapat memahami secara mendalam tentang fenomena alam adalah dengan melatih siswa untuk bernalar.

Menurut Small (1996), bernalar merupakan suatu penjelasan yang menunjukkan kaitan atau hubungan antara dua hal atau lebih yang atas dasar alasan-alasan tertentu dan dengan langkah-langkah tertentu sampai pada kesimpulan. Bernalar juga dikatakan sebagai proses berpikir logis yang menggunakan induktif dan deduktif untuk menarik suatu kesimpulan (Santrock, 2008). Kemampuan bernalar siswa dapat diukur melalui tingkatantingkatan kemampuan bernalar menggunakan Taksonomi SOLO. Taksonomi SOLO, dapat membantu usaha menggambarkan kompleksitas pemahaman siswa tentang subjek, melalui lima tingkat respons, dan diklaim dapat diterapkan di setiap wilayah subjek. Menurut Biggs and Collis (1982), lima tingkat kemampuan bernalar siswa terdiri dari level yang paling bawah yaitu prastruktural, tingkat diatasnya adalah unistruktural, berikutnya multistruktural, relasional, dan tingkat yang paling tinggi adalah abstrak diperluas (extended abstrack).

Tingkatan kualitas kemampuan bernalar pada Taksonomi SOLO menurut Kuswana (2012) adalah sebagai berikut:

1. Prestuktural

Pada tahap ini para siswa hanya memperoleh potongan-potongan dari informasi yang terlepas dari satu sama lain yang tidak terorganisasi dan tidak ada artinya. Siswa tidak dapat menjawab soal dengan benar, jawaban yang berbeda atau menyimpang dengan soal, dan yang lebih sering terjadi adalah jawaban berupa ulangan dari soal atau soal ditulis kembali. Jawaban dari pertanyaan atau permasalahan yang membingungkan.

2. Unistruktural

Koneksi-koneksi dibuat jelas, nyata dan sederhana tetapi maknanya tidak diserap. Siswa dapat menyatakan kesimpulan jawaban dari sebuah permasalahan berdasarkan satu data yang cocok dan dianggap benar. Ketika diberikan soal maka siswa hanya dapat memberikan satu jawaban yang terkait dengan soal.

3. Multistruktural
Pada kriteria ini, siswa menggunakan prosesproses dasar untuk memilih respon terbaik dari beberapa pilihan dan mengumpulkan informasi yang diperlukan sebagai jawaban atas pertanyaan atau permasalahan yang diberikan. Kriteria tingkat kemampuan bernalar multistruktural yaitu siswa dapat membuat kesimpulan berdasarkan dua data atau lebih atau membuat kesimpulan jawaban dengan menyertakan dua atau lebih alternatif jawaban yang sesuai. Tetapi jawaban yang diberikan tidak ada keterkaitan satu sama lain.

\section{Relasional}

Siswa mampu menghargai makna dari hubungan bagian dengan keseluruhan informasi atau dengan kata lain siswa mampu menghubungkan data-data secara logis dan menyempurnakan kesimpulan jawaban yang dibuat berdasarkan data dan konsep yang sesuai. Mampu menghubungkan atau mengaitkan jawaban yang satu dengan yang lainnya.

5. Abstrak diperluas

Siswa membuat hubungan-hubungan tidak hanya di dalam bidang hal yang diberikan, juga ada yang datang dari luar (mampu menggeneralisasi dan memindahkan prinsip dan gagasan-gagasan yang spesifik). Siswa mampu berpikir secara deduktif dan induktif, dapat mengadakan suatu hubungan, membuat hipotesis, dan mampu menarik kesimpulan berdasarkan pengalaman ataupun kesimpulan secara umum tanpa didasari pengalaman atau pengetahuan sebelumnya. Siswa pada tingkat ini, jika diberikan suatu soal maka akan dapat menyelesaikan dengan memberikan dua atau lebih jawaban yang saling terkait satu sama lain, tetapi terkadang ada pula jawaban yang keluar dari soal.

Kemampuan bernalar awal dapat diajarkan kepada siswa sekolah dasar melalui proses sosial untuk berinteraksi dengan sesama di lingkungan sekitar tempat tinggal. Dasar tersebut akan menjadi pedoman guru untuk melatih siswa SD dalam bernalar, sehingga siswa bisa mendapatkan pengetahuan tentang alam sekaligus kemampuan berinteraksi dengan lingkungan tempat tinggal.

Kenyataannya, bahwa kemampuan siswa SD dalam bernalar masih sangat rendah. Berdasarkan hasil uji kemampuan bernalar tentang materi perkembangbiakan tumbuhan dan hewan, yang dilakukan oleh peneliti di SDI Surya Buana Malang bahwa dari 28 siswa kelas VI hanya 17\% siswa dengan standar tingkat kemampuan bernalar pada tingkat multistruktural (kemampuan bernalar tingkat 2 untuk usia 10-12 tahun) berdasarkan Taksonomi Solo, dan sisanya masih berada pada level prastruktural (kemampuan bernalar tingkat 1 untuk usia 7-9 tahun) dan unistruktural (kemampuan bernalar tingkat dasar untuk usia 4-6 tahun). Kondisi tersebut membuktikan bahwa 
penalaran perlu dilatihkan kepada siswa agar siswa lebih memahami dan mengerti dengan jelas materi pembelajaran yang diberikan di sekolah, salah satunya pada materi perkembangbiakan tumbuhan dan hewan.

Dalam kegiatan pembelajaran, siswa belum diberi fasilitas untuk berpikir ilmiah dan bernalar. Rencana pembelajaran yang dibuat belum memotivasi siswa untuk bernalar, sehingga siswa hanya melakukan kegiatan pengamatan dan mengisi lembar kerja dengan jawaban yang tidak berdasarkan hasil pengamatan melainkan sesuai dengan materi yang terdapat pada buku ajar. Buku yang digunakan dalam pembelajaran IPA sudah menuntun siswa untuk melakukan kegiatan penemuan dan mengharuskan siswa untuk dapat bernalar. Namun, buku ajar yang digunakan siswa belum dapat memancing siswa untuk bernalar dan mengajukan pertanyaan serta belum mendukung siswa untuk menemukan masalah.

Melatih siswa untuk bernalar dapat dilakukan oleh guru dengan cara, menggali pemahaman dasar atau pengetahuan tentang materi pembelajaran, menemukan bukti-bukti yang sesuai, meluruskan dua hal yang saling berlawanan, membimbing siswa untuk berpendapat sesuai materi, dan menggunakan strategi pemecahan masalah (Biggs \& Collis, 1982). Termasuk dalam kegiatan pembelajaran tentang perkembangbiakan tumbuhan dan hewan, dapat dilakukan melalui kegiatan observasi dan eksperimen yang berbasis penemuan atau inkuiri (Khaeruddin, dkk., 2005). Menurut Suryanti, dkk. (2008), pembelajaran inkuiri atau pembelajaran penemuan merupakan suatu model yang menekankan pentingnya membantu siswa memahami struktur atau ide kunci dari suatu disiplin ilmu melalui penemuan pribadi. Pembelajaran berbasis inkuiri menekankan kepada proses mencari dan menemukan, sehingga materi pelajaran tidak diberikan secara langsung oleh guru melainkan siswa yang berperan aktif untuk mencari dan menemukan sendiri materi pelajaran, sedangkan guru berperan sebagai fasilitator dan pembimbing siswa untuk belajar (Sanjaya, 2006).

Pengetahuan yang didapat dengan temuan sendiri, akan menjadi lebih diingat dan masuk dalam memori jangka panjang siswa, dan tidak akan mudah hilang. Pembelajaran yang berpusat pada siswa, dapat dilakukan dengan menggunakan model pembelajaran inkuri yang bersifat terbimbing (Bass, et al., 2009). Pembelajaran berbasis inkuiri terbimbing, dapat dilakukan oleh guru dengan memanfaatkan media yang berbasis kontekstual untuk memberikan suatu masalah kepada siswa (Wena, 2012), sehingga siswa tidak perlu memikirkan masalahnya tetapi tugas siswa adalah mencari jawaban atau solusi untuk masalah yang diberikan baik secara individu maupun kelompok.
Pembelajaran berbasis inkuiri terbimbing dapat diterapkan kepada siswa melalui beberapa langkah antara lain, simulasi, perumusan masalah, pengumpulan data, analisis data, verifikasi, dan generalisasi/penyampaian jawaban kesimpulan (Suyono \& Hariyanto, 2015).

Materi ajar tentang perkembangbiakan tumbuhan dan hewan merupakan materi yang mengharuskan siswa untuk menemukan dan membuktikan kebenaran tentang cara, proses, dan hasil dari tumbuhan dan hewan dalam melakukan proses perkembangbiakan. Materi tersebut masih bersifat abstrak atau luas untuk dipahami siswa SD, sehingga perlu adanya media yang dapat membantu siswa untuk berpikir lebih mudah tentang konsep perkembangbiakan tumbuhan dan hewan. Media tersebut berupa buku Pop Up.

Buku Pop Up merupakan merupakan bagian dari "Moveable book" yang mana buku ini memiliki halaman dengan bagian-bagian gambar yang tertumpuk kemudian jika dibuka, bagian-bagian gambar yang tertumpuk akan terangkat seperti keluar dari halaman buku dan saat buku ditutup, gambar-gambar yang terangkat, akan kembali terlipat dan mendatar (Benjamin, et al., 2013). Pop up merupakan suatu ilustrasi berupa gambar yang dapat berdiri tegak ketika halaman buku dibuka, dikembangkan oleh British Publisher S. Louis Giraud pada 1929. Karya-karya S. Louis Giraud banyak disukai dalam bentuk buku dengan ilustrasi pop up yang bagus disebut dengan "model hidup" (Montanero, 2005 dalam Klein et al., 2015).

Pop up umumnya dianggap sebagai benda tiga dimensi yang berdiri secara otomatis ketika selembar kartu atau buku yang telah dilipat dua dibuka terbentang 180 derajat, dengan struktur gambar yang direkatkan pada halaman satu dan halaman berikutnya agar gambar dapat terbentuk dan berdiri menyebar saat buku dibuka (Jackson, 1988). Gambar untuk menjelaskan perkembangbiakan tumbuhan dan hewan, akan dibuat sedemikian rupa untuk dapat menunjukkan cara perkembangbiakan yang dilakukan oleh tumbuhan dan hewan. Buku tidak hanya menampilkan gambar dua dimensi, melainkan juga menampilkan sensasi tiga dimensi.

Buku pop up yang digunakan sebagai media untuk meningkatkan kemampuan bernalar terdapat dua jenis yaitu buku perkembangbiakan tumbuhan dan buku perkembangbiakan hewan. Buku perkembangbiakan tumbuhan terdapat pada Gambar 1. Buku pop up berisi tentang pertanyaan menantang yang dapat menarik perhatian siswa untuk mengemukakan jawaban sementara (hipotesis) dari pertanyaan yang terdapat pada buku pop up. Selain itu, dengan buku ini diharapkan siswa juga dapat mengemukakan pertanyaan berdasarkan gambar pop up yang dilihat. 
Berdasarkan hal tersebut, siswa juga dapat berperan aktif untuk memberikan pertanyaan atau permasalahan yang berasala dari buku pop up tumbuhan. Buku pop up tumbuhan terdiri dari 13 halaman yang berisi tentang perkembangbiakan secara generatif dan perkembangbiakan vegetatif.

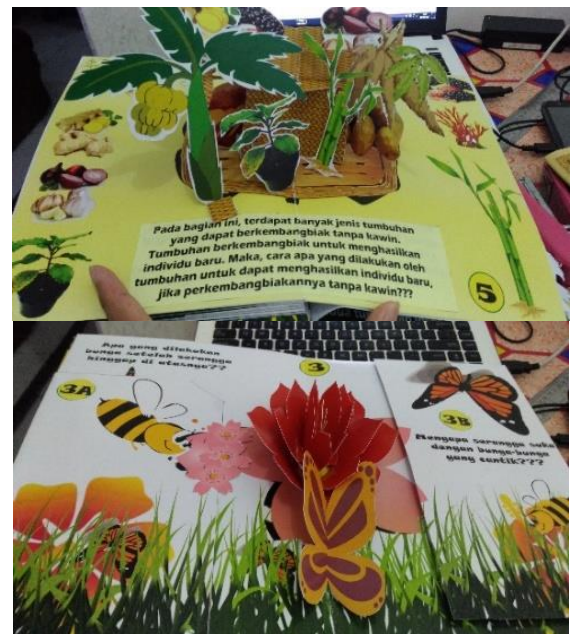

Gambar 1. Buku Pop Up Perkembangbiakan Tumbuhan

Buku perkembangbiakan hewan berisi tentang gambar-gambar hewan yang berkembang biak secara ovipar (bertelur), vivipar (melahirkan), dan ovovivipar (bertelur dan melahirkan). Buku pop up perkembangbiakan hewan terdapat pada Gambar 2. Buku ini berisi 9 gambar hewan yang terdiri dari hewan panda, kadal, sapi, harimau, kupu-kupu, ular, buaya, ikan, dan lumba-lumba. Buku tersebut juga berisi pertanyaan-pertanyaan menantang agar siswa dapat berargumen untuk menjawab setiap pertanyaan yang ada. Selain itu, pertanyaan digunakan untuk merangsang siswa untuk bertanya.

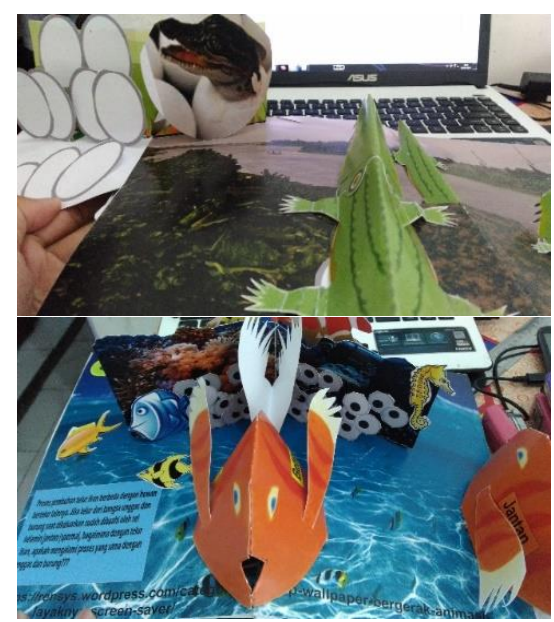

Gambar 2. Buku Pop Up

Perkembangbiakan Hewan
Pengembangan buku pop up merupakan terobosan yang dilakukan oleh peneliti untuk mencoba menuntun siswa untuk bernalar dengan bantuan gambar, agar siswa terbantu dalam menemukan jawaban dari setiap permasalahan atau pertanyaan dalam mempelajari perkembangbiakan tumbuhan dan hewan. Penelitian akan dilakukan dengan tujuan untuk mengembangkan perangkat pembelajaran inkuiri terbimbing yang layak serta untuk membantu siswa dalam meningkatkan kemampuan bernalarnya dengan berbantuan media buku pop up.

\section{METODE}

Penelitian yang dilakukan adalah penelitian pengembangan untuk mengembangkan perangkat pembelajaran inkuiri terbimbing yang layak diterapkan pada siswa kelas VI SD untuk meningkatkan kemampuan bernalar siswa. Pembelajaran dilakukan dengan berbantuan media buku pop up. Sasaran penelitian pada kelas VI SD di SD Islam Surya Buana Malang dengan jumlah siswa sebanyak 47 siswa, yang dibagi menjadi dua kelompok kelas yaitu kelas VI A sebanyak 24 siswa dan kelas VI B sebanyak 23 siswa. Prosedur pelaksanaan penelitian mengikuti prosedur yang ditetapkan oleh Thiagarajan, Semmel, and Semmel yaitu 4D Models yang terdiri dari 4 tahap pelaksanaan penelitian yaitu, define (tahap pendefinisian), design (tahap perancangan), develop (pengembangan), dan disseminate (penyebaran).

Desain penelitian pengembangan menggunakan rancangan One Group Pretest-Posttes untuk melihat hasil peningkatan kemampuan siswa sebelum dan sesudah diberi perlakuan pembelajaran inkuiri terbimbing berbantuan media buku pop up. Bentuk dari desain rancangan penelitian adalah sebagai berikut,

Keterangan:

\section{$\mathrm{O}_{1} \mathrm{X}^{\mathrm{O}_{2}}$}

01: Pretes (tes awal) untuk mengukur pemahaman dan kemampuan bernalar siswa tentang perkembangbiakan tumbuhan dan hewan sebelum diberi perlakuan.

O2: Postes (tes akhir) untuk mengukur pemahaman dan kemampuan bernalar siswa tentang perkembangbiakan tumbuhan dan hewan setelah diberi perlakuan pada kelas eksperimen.

$\mathbf{X}$ : Perlakuan yang diberikan kepada kelompok siswa berupa bantuan pembelajaran dengan media buku pop up.

Teknik pengumpulan data menggunakan metode observasi/pengamatan untuk mendapatkan data tentang keterlaksanaan rencana pembelajaran yang telah dibuat dan untuk mendapatkan aktivitas tertinggi yang dilakukan oleh siswa saat 
pembelajaran berlangsung. Metode tes untuk mengetahui kemampuan siswa dalam bernalar, serta dengan metode angket/kuesioner untuk mengetahui respon siswa terhadap kegiatan pembelajaran yang telah dilaksanakan.

Teknik analisis data yang digunakan dalam penelitian adalah deskriptif kuantitatif dengan menentukan nilai validitas perangkat pembelajaran, prosentase keterlaksanaan pembelajaran, skor kualitas pembelajaran yang dilakukan, level kemampuan bernalar yang didasarkan pada rubrik kemampuan bernalar yang mengacu pada Taksonomi SOLO, signifikansi tingkat kemampuan bernalar dengan t-test dengan syarat signifikansi jika $t_{\text {hitung }}>\mathrm{t}_{\text {tabel }}$ (Supardi, 2013:325), serta derajat perbedaan atau perubahan nilai pretes dan postes dengan menggunakan $\mathrm{N}$-gain dengan kriteria hasil menurut (Hake, 1999:1) yaitu, nilai g > 0,7 dengan perbedaan nilai yang tinggi, $0,3<\mathrm{g}<0,7$ dengan perbedaan nilai yang sedang, dan nilai $\mathrm{g}<0,3$ dengan perbedaan nilai yang rendah.

\section{HASIL DAN PEMBAHASAN}

Hasil penelitian yang telah dilakukan di SD Islam Surya Buana untuk membuktikan bahwa pembelajaran inkuiri terbimbing berbantuan media buku pop up dapat meningkatkan kemampuan bernalar siswa kelas VI SD, terdiri dari, 1) validitas perangkat pembelajaran inkuiri terbimbing, 2) keterlaksanaan pembelajaran inkuiri terbimbing di kelas VI A dan VI B, 3) aktivitas yang sering dilakukan siswa VI A dan VI B saat proses pembelajaran inkuiri terbimbing berlangsung, 4) hasil peningkatan kemampuan bernalar siswa kelas VI A dan VI B, dan 5) respon siswa terhadap kegiatan pembelajaran di kelas VIA dan VIB.

Validitas perangkat pembelajaran terdiri dari validitas silabus, rencana pelaksanaan pembelajaran (RPP), lembar kegiatan siswa (LKS), dan tes kemampuan bernalar. Hasil validasi perangkat terdapat pada Tabel 1 .

Tabel 1. Hasil Validasi Perangkat

\begin{tabular}{|c|c|c|c|c|}
\hline No & Jenis Validasi & Aspek yang divalidasi & $\begin{array}{c}\text { Skor } \\
\text { Validasi } \\
\end{array}$ & Keterangan \\
\hline \multirow[t]{3}{*}{1} & \multirow[t]{3}{*}{ Silabus } & Format & 4,2 & Sangat valid \\
\hline & & Bahasa & 4,4 & Sangat valid \\
\hline & & Isi & 4,3 & Sangat valid \\
\hline \multirow[t]{4}{*}{2} & RPP 1 & 20 aspek penilaian & 4,4 & Sangat valid \\
\hline & RPP 2 & 20 aspek penilaian & 4,5 & Sangat valid \\
\hline & RPP 3 & 20 aspek penilaian & 4,3 & Sangat valid \\
\hline & RPP 4 & 20 aspek penilaian & 4,5 & Sangat valid \\
\hline \multirow[t]{7}{*}{2} & \multirow[t]{4}{*}{ LKS 1} & Materi & 3,8 & Valid \\
\hline & & Kebahasaan & 4,2 & Sangat valid \\
\hline & & Penyajian & 4,4 & Sangat valid \\
\hline & & $\begin{array}{l}\text { Inovasi dan mutu } \\
\text { kegiatan pembelajaran }\end{array}$ & 4,4 & Sangat valid \\
\hline & LKS 2 & Sda & 4,5 & Sangat valid \\
\hline & LKS 3 & Sda & 4,4 & Sangat valid \\
\hline & LKS 4 & Sda & 4,5 & Sangat valid \\
\hline \multirow[t]{2}{*}{3} & \multirow{2}{*}{$\begin{array}{l}\text { Tes Kemampuan } \\
\text { Bernalar }\end{array}$} & Format & 4,3 & Sangat valid \\
\hline & & Isi & 4,2 & Sangat valid \\
\hline
\end{tabular}

Berdasarkan hasil validasi silabus, LKS, dan tes kemampuan bernalar yang terdapat pada Tabel 1, hasil validasi oleh pakar terhadap perangkat pembelajaran inkuiri terbimbing yang telah dikembangkan dinyatakan sangat valid.
Berdasarkan pedoman klasifikasi penilaian perangkat pembelajaran oleh Restiadi (2013:109), rentangan skor validasi perangkat pembelajaran untuk menentukan suatu perangkat dinyatakan valid atau tidak terdapat pada Tabel 2.

Tabel 2. Pedoman Klasifikasi Penilaian Perangkat Pembelajaran

\begin{tabular}{cc}
\hline Interval Skor & Kriteria \\
\hline $\mathrm{x} \leq 1,0$ & Tidak valid \\
\hline $1,1 \leq \mathrm{x} \leq 2,0$ & Kurang valid \\
\hline $2,1 \leq \mathrm{x} \leq 3,0$ & Cukup baik \\
\hline $3,1 \leq \mathrm{x} \leq 4,0$ & Baik \\
\hline $4,1 \leq \mathrm{x} \leq 5,0$ & Sangat Baik \\
\hline & (Sumber: Restiadi, 2013)
\end{tabular}


Hasil validasi silabus berdasarkan format, bahasa, dan isi dengan 15 kriteria penilaian, menunjukkan rata-rata hasil validasi dari 2 validator ahli, dengan kriteria yang sangat valid yaitu sebesar 4,34. Hasil validasi RPP untuk 4 kali pertemuan, menunjukkan rata-rata skor validasi sebesar 4,4 , sehingga dapat dinyataka bahwa RPP yang digunakan selama proses pembelajaran juga sangat valid. Rata-rata skor validasi LKS yang digunakan selama 4 kali pertemuan sebesar 4,31, sedangkan rata-rata skor validasi tes kemampuan bernalar sebesar 4,25. Berdasarkan hasil validasi tersebut dapat dinyatakan bahwa ketiga perangkat pembelajaran inkuiri terbimbing, sangat valid karena rata-rata skor nilai validasi dari 2 orang pakar di atas 4,1 $(>4,1)$. Hal ini sesuai dengan pendapat Widoyoko (2011:225) bahwa hasil validasi perangkat dapat dikategorikan sangat valid jika nilai yang didapatkan $\geq 4,20$.

Keterlaksanaan pembelajaran merupakan berlangsungnya kegiatan pembelajaran inkuiri terbimbing pada materi perkembangbiakan tumbuhan dan hewan. Prosentase keterlaksanaan pembelajaran inkuiri terbimbing terdapat pada Tabel 3. Pembelajaran dikelompokkan menjadi 3 kelompok kegiatan yaitu kegiatan pendahuluan, inti, dan penutup.

Tabel 3. Prosentase Keterlaksanaan Pembelajaran dan Skor Proses Pembelajaran di Kelas VI A

\begin{tabular}{cccccccccc}
\hline \multirow{2}{*}{ No } & $\begin{array}{c}\text { Kegiatan } \\
\text { yang diamati }\end{array}$ & \multicolumn{3}{c}{$\begin{array}{c}\text { Rata-rata Nilai Pengamatan } \\
\text { tiap Pertemuan }\end{array}$} & \multicolumn{5}{c}{$\begin{array}{c}\text { Reliabilitas Hasil Amatan tiap } \\
\text { Pertemuan }\end{array}$} \\
\cline { 2 - 10 } & $\mathbf{1}$ & $\mathbf{2}$ & $\mathbf{3}$ & $\mathbf{4}$ & $\mathbf{1}$ & $\mathbf{2}$ & $\mathbf{3}$ & $\mathbf{4}$ \\
\hline 1 & Pendahuluan & 4,4 & 4,2 & 4,6 & 4,8 & 100 & 100 & 90,56 & 95,56 \\
\hline 2 & Inti & 4,07 & 4,92 & 3,79 & 4,59 & 96,6 & 100 & 91,17 & 96,97 \\
\hline 3 & Penutup & 4,13 & 4,5 & 3,13 & 4 & 96,43 & 93,65 & 96,43 & 100 \\
\hline \multirow{2}{*}{$\begin{array}{c}\text { Persentase } \\
\text { Keterlaksanaan (\%) }\end{array}$} & 100,00 & 90,48 & 85,71 & 95,00 & 100,00 & 100,00 & 100,00 & 100,00 \\
\hline
\end{tabular}

Prosentase keterlaksanaan pembelajaran inkuiri terbimbing di kelas VI A, berdasarkan data pada Tabel 3 menunjukkan bahwa di pertemuan pertama semua kegiatan pembelajaran terlaksana $100 \%$. Tetapi, pada pembelajaran kedua sampai keempat, pembelajaran tidak terlaksana $100 \%$. Hal ini dikarenakan waktu yang digunakan pada setiap pertemuan relatif singkat, sedangkan masih ada beberapa anak yang membutuhkan penjelasan materi yang perlu diulang-ulang agar semua siswa dapat memahami materi yang disampaikan. Tidak semua siswa langsung dapat memahami materi yang disampaikan, sehingga perlu penjelasan yang berulang-ulang yang dapat menghabiskan waktu lebih lama. Lebih jelasnya mengenai skor kegiatan pembelajaran yang dilakukan di kelas VIA, dapat dilihat pada Gambar 3.

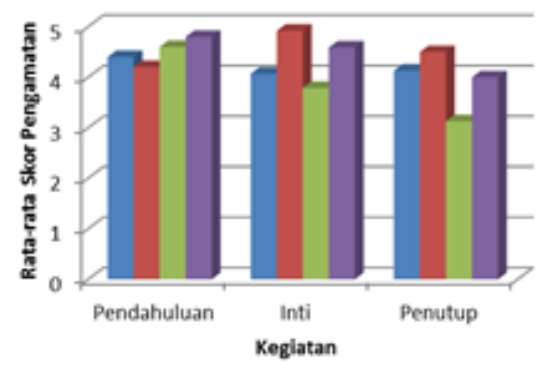

- Pertemuan 1 =Pertemuan 2 Eertemuan 3 = Pertemuan 4

Gambar 3. Grafik Skor Kegiatan Pembelajaran di Kelas VI A

Dapat diketahui dari Gambar 3, bahwa kegiatan pembelajaran yang belangsung di kelas VI A dikategorikan baik, karena skor di setiap kegiatan mendapat nilai di atas $3(>3)$.

Sama halnya dengan keterlaksaan pembelajaran inkuiri terbimbing di kelas VI A, bahwa di kelas VI B prosentase keterlaksanaan $100 \%$ hanya terdapat pada pertemuan pertama dan kedua. Pembelajaran ketiga dan keempat tidak lagi 100\% melainkan di bawahnya. Adapun untuk lebih jelasnya, terdapat pada Gambar 4.

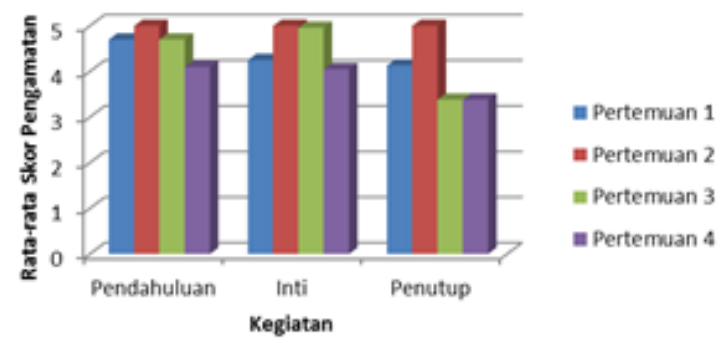

Gambar 4. Grafik Skor Kegiatan Pembelajaran di Kelas VI B

Skor kegiatan pembelajaran dapat dikategorikan sudah baik, sehingga pembelajaran inkuiri terbimbing untuk meningkatkan kemampuan bernalar di kelas VI B dapat terlaksana dengan baik.

Aktivitas siswa yang menunjukkan terlaksananya pembalajaran inkuiri terbimbing dapat diketahui pada Gambar 5. Terdiri dari 8 aktivitas diantaranya, 7 kegiatan dalam proses pembelajaran dan 1 kegiatan tidak dalam proses pembelajaran. 


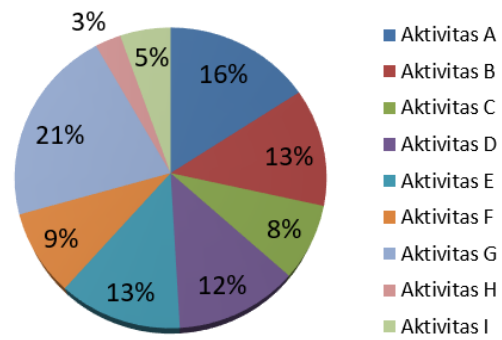

Gambar 5. Grafik Prosentase Aktivitas Siswa selama Pembelajaran di Kelas VIA

Aktivitas A: Memperhatikan guru saat memberikan informasi

Aktivitas B : Mengamati dan membaca buku ajar pop up

Aktivitas C : Menyampaikan pendapat atau jawaban pertanyaan

Aktivitas D : Melakukan diskusi dengan kelompok

Aktivitas E : Mendengarkan guru/teman yang sedang menjawab pertanyaan atau mempresentasikan jawaban

Aktivitas F : Menulis/mencatat segala informasi selama proses pembelajaran

Aktivitas G : Melakukan penyelidikan atau percobaan bersama teman

Aktivitas H : Membacakan/menyimpulkan jawaban dari hasil diskusi bersama teman

Aktivitas I : Tidak berada dalam kondisi belajar

Berdasarkan data hasil pengamatan aktivitas siswa di kelas VI A, selama 4 kali pertemuan, dapat diketahui bahwa aktivitas belajar yang sering dilakukan oleh siswa adalah aktivitas $G$ yaitu melakukan penyelidikan atau percobaan bersama teman dengan prosentase $21,23 \%$. Selain itu, aktivitas A yaitu mengamati guru yang sedang memberikan informasi serta aktivitas B yaitu mengamati buku pop up juga sering dilakukan oleh siswa kelas VIA. Aktivitas yang dilakukan oleh siswa kelas VIB terdapat pada Gambar 6.

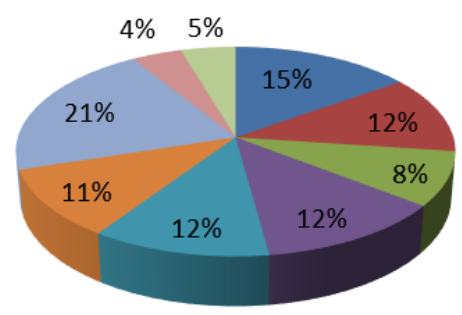

- Aktivitas A

aktivitas B

- Aktivitas C

- Aktivitas D

aktivitas $\mathrm{E}$

aktivitas F

Aktivitas $\mathrm{G}$

Aktivitas $\mathrm{H}$

aktivitas I

Gambar 6. Grafik Prosentase Aktivitas Siswa selama Pembelajaran di Kelas VI B

Berdasarkan data hasil pengamatan aktivitas siswa di kelas VI B, selama 4 kali pertemuan, dapat diketahui bahwa aktivitas belajar yang sering dilakukan oleh siswa VI B sama dengan siswa VI A yaitu melakukan penyelidikan atau percobaan bersama teman dengan prosentase 21,31\%. Aktivitas lain yang sering dilakukan oleh siswa kelas VI B yaitu aktivitas A yaitu mengamati guru saat memberikan informasi serta aktivitas B yaitu mengamati buku pop up.

Berdasarkan teori yang terdapat di Curriculum and Evaluation Standards (NCTM, 1989) dalam Minarni (2010:479), memberikan tanda-tanda saat proses penalaran sedang berlangsung yaitu bila siswa: a) menggunakan metode coba-ralat dan bekerja mundur untuk menyelesaikan masalah, b) membuat dan mengaji dugaan, dan c) menciptakan argumen. Menciptakan argumen atau pendapat berupa jawaban untuk suatu masalah adalah aktivitas yang sering dilakukan siswa kelas VI SD saat pelaksanaan kegaitan pembelajaran. Menurut Benjamin, Zhbanova, Alkouri, \& Rule (2013) bahwa di saat siswa sedang menyusun kotak pop up, mereka mengutarakan pendapatnya tentang susunan pop up yang akan dibuat beserta dengan alasanalasan yang masuk akal.

Hasil penelitian yang menunjukkan peningkatan kemampuan bernalar siswa kelas VI A, terdapat pada Gambar 7. Kemampuan bernalar siswa mengalami peningkatan dari tingkat prastruktural $(S=0)$ menjadi multistruktural $(S=2)$, dan ada beberapa siswa yang kemampuan bernalarnya meningkat sampai tingkat relasional $(\mathrm{S}=3)$.

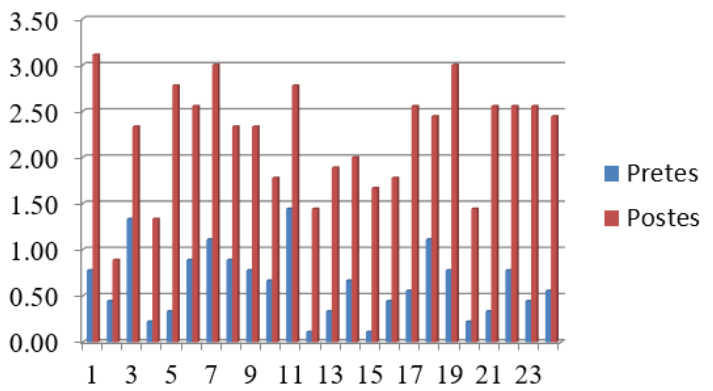

Gambar 7. Grafik Peningkatan Level Kemampuan Bernalar Siswa Kelas VI A

Berdasarkan Gambar 7, sebelum siswa diberi perlakuan dengan pembelajaran inkuiri terbimbing berbantuan media buku pop up, hasil pretes menunjukkan kemampuan bernalar siswa pada tingkat prastruktural (dengan skor $0,00-0,49$ ) dan pada tingkat unistruktural $(0,50-1,49)$. Setelah mendapatkan pembelajaran inkuiri terbimbing berbantuan buku pop up, kemampuan bernalar siswa meningkat hingga tingkat multisruktural $(1,50$ - 2,49) dan ada beberapa siswa yang meningkat sampai tingkat relasional $(2,50-3,49)$. Hasil yang tidak jauh berbeda dengan kemampuan bernalar siswa kelas VI B, terdapat pada Gambar 8 . 


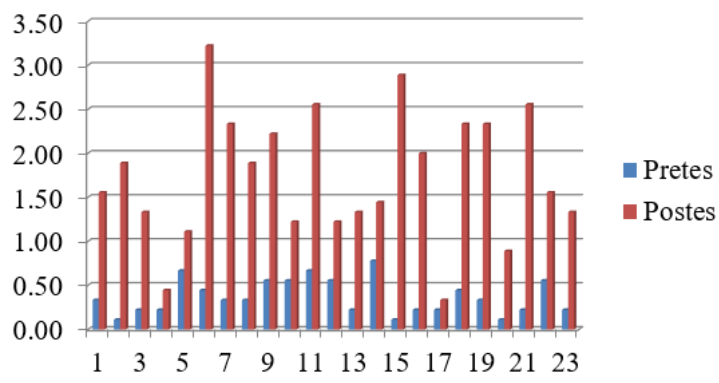

Gambar 8. Grafik Peningkatan Level Kemampuan Bernalar Siswa Kelas VI B
Hasil tes kemampuan bernalar siswa kelas VI A dan VI B jika diprosentasekan kenaikan level dari sebelum perlakuan dan sesudah perlakuan dapat dilihat pada Tabel 5. Tabel tersebut menunjukkan rekapitulasi prosentase perbedaan tingkat kemampuan bernalar siswa di kelas VI A dan VI B.

Tabel 5. Rekap Hasil Tes Kemampuan Bernalar Siswa Kelas VI A dan VI B

\begin{tabular}{cccccc}
\hline \multirow{2}{*}{ No } & $\begin{array}{c}\text { Tingkatan } \\
\text { Kemampuan } \\
\text { Bernalar }\end{array}$ & $\begin{array}{c}\text { Prosentase Level Kemampuan } \\
\text { Bernalar VI A }\end{array}$ & \multicolumn{2}{c}{$\begin{array}{c}\text { Prosentase Level } \\
\text { Kemampuan Bernalar VI B }\end{array}$} \\
\cline { 3 - 6 } 1 & Prastruktural & $41,7 \%$ & $0,0 \%$ & $69,6 \%$ & $8,7 \%$ \\
\hline 2 & Unistruktural & $58,3 \%$ & $16,7 \%$ & $30,4 \%$ & $34,8 \%$ \\
\hline 3 & Multistruktural & $0 \%$ & $41,7 \%$ & $0 \%$ & $39,1 \%$ \\
\hline 4 & Relasional & $0 \%$ & $41,7 \%$ & $0 \%$ & $17,4 \%$ \\
\hline 5 & $\begin{array}{c}\text { Abstrak } \\
\text { Diperluas }\end{array}$ & $0 \%$ & $0,0 \%$ & $0 \%$ & $0,0 \%$ \\
\hline
\end{tabular}

Berdasarkan data yang terdapat pada Tabel 5, Prosentase kemampuan bernalar yang sebelumnya berada pada tingkat 0 dan 1 , setelah diberi perlakuan kegiatan pembelajaran, siswa dengan kemampuan bernalar tingkat 0 dan 1 berkurang dan muncul kemampuan bernalar tingkat 2 dan 3 .

Perhitungan skor kemampuan bernalar yang digunakan dalam penelitian ini sesuai dengan penelitian yang dilakukan oleh Brabrand et al. (2015:6) bahwa penentuan rata-rata skor untuk menentukan tingkatan pada Taksonomi SOLO dilakukan dengan menentukan nilai rata-rata dari skor yang didapat dari jumlah soal yang ada.

Hasil tes awal untuk mengetahui tingkat kemampuan bernalar juga dilakukan oleh Ramsden (1998) dalam Potter \& Kustra (2012:15) dengan hasil studi bahwa tingkat kemampuan awal seseorang sebelum diberikan perlakuan berupa pembelajaran oleh insruktur dengan mengaitkan kehidupan nyata berada di posisi prastruktural dan unistruktural. Sesuai pendapat Biggs \& Collis (1982:25) bahwa kemampuan berpikir untuk siswa kelas VI SD dengan usia rata-rata 12 tahun, level kemampuan bernalar berada di multistruktural. Kemampuan bernalar pada tingkat relasional hanya diperoleh oleh 10 siswa di kelas VI A dan 4 orang di kelas VI B.

Analisis signifikansi kenaikan tingkat kemampuan bernalar siswa dianalisis menggunakan uji $\mathrm{t}$ berpasangan (Paired $t$-test). Hasil uji $\mathrm{t}$ menunjukkan, nilai $t_{\text {hitung }}$ adalah 16,172 , sehingga dapat disimpulkan bahwa $t_{\text {hitung }}>\mathrm{t}_{\text {tabel }}$, sehingga dapat disimpulkan bahwa kenaikan tingkat kemampuan bernalar siswa kelas VI A meningkat secara signifikan. Begitu juga kenaikan tingkat kemampuan bernalar pada siswa kelas VI B, setelah dianalisis menggunakan uji t berpasangan, nilai $t_{\text {hitung }}$ adalah 9,094. Berdasarkan hasil tersebut, nilai $t_{\text {hitung }}>t_{\text {tabel }}$, sehingga terbukti bahwa kenaikan tingkat kemampuan bernalar siswa kelas VI B, meningkat secara signifikan.

Respon siswa menunjukkan bahwa 100\% siswa kelas VI A beranggapan bahwa pembelajaran untuk meningkatkan kemampuan bernalar dengan berbantuan buku pop up sangat menarik dan dapat membantu siswa untuk lebih mudah memahami pelajaran, serta buku pop up yang digunakan menarik serta dapat membantu memahami materi perkembangbiakan tumbuhan dan hewan. Tetapi, ada sebagian siswa sebanyak $12,5 \%$ yang beranggapan bahwa merasa belum mampu mengingat hasil pembelajaran, serta ada $8,3 \%$ yang merasa belum mampu bernalar dengan bantuan buku ajar pop up. Selain itu, juga ada beberapa siswa yang merasa bosan jika materi perkembangbiakan diulang kembali.

Respon siswa kelas VI B terhadap kegiatan pembelajaran juga positif, bahwa siswa dapat melaksanakan pembelajaran dengan baik. Walaupun demikian, ada pula respon dari beberapa siswa yang belum mampu mengingat hasil belajar, masih merasa susah dalam memahami pelajaran, dan ada juga yang masih belum dapat menjawab soal dengan mudah. Tetapi buku ajar pop up yang digunakan dapat membantu siswa kelas VI B untuk bernalar dan dapat membantu siswa untuk 
memahami materi perkembangbiakan tumbuhan dan hewan. Seperti halnya dengan siswa VI A, beberapa siswa VI B juga ada yang merasa bosan jika materi perkembangbiakan tumbuhan dan hewan diulang kembali. Siswa menginginkan materi pembelajaran yang lain dengan tetap menggunakan buku pop up yang menarik.

Walaupun demikian seluruh siswa merasa baru dan senang dengan pembelajaran yang disampaikan dengan berbantuan media buku pop up. Respon positif yang diberikan oleh siswa menunjukkan bahwa siswa antusias dengan pembelajaran yang disajikan. Hal ini dapat memotivasi siswa untuk meningkatkan perhatian dan membuat mereka terlibat dalam pengalaman belajar yang menyenangkan dan bermakna (Nur, 2010). Tetapi dalam kegiatan pembelajaran, juga didapatkan beberapa kendala atau hambatan dalam menerapkan pembelajaran dengan model inkuiri terbimbing berbantuan buku pop up seperti, siswa masih belum terbiasa untuk bernalar dalam menyelesaikan soal, sehingga kesulitan dalam menyampaikan pendapat. Siswa terbiasa menunggu jawaban dari guru, sehingga merasa kesulitan dalam memikirkan sendiri jawaban dari suatu soal. Selain itu, Siswa cenderung menggunakan buku pop up hanya untuk dilihatlihat saja, tidak dimanfaatkan untuk menjawab soal. Kendala lainnya adalah siswa mengerjakan soal yang terdapat dalam LKS dengan waktu yang sangat lama, sehingga ada kegiatan yang tidak terselesaikan.

\section{PENUTUP}

Berdasarkan hasil penelitian yang telah dilakukan, dapat disimpulkan bahwa perangkat pembelajaran IPA pada materi perkembangbiakan tumbuhan dan hewan berbasis inkuiri terbimbing berbantuan media buku pop up layak untuk diterapkan pada siswa kelas VI SD serta meningkatkan kemampuan bernalar siswa kelas VI SD.

Berdasarkan hasil penelitian yang telah dilakukan, guru harus memperhatikan pengelolaan waktu dan pembimbingan kepada siswa agar kegiatan pembelajaran berbasis inkuiri terbimbing dapat terlaksana dengan baik.

\section{DAFTAR PUSTAKA}

Benjamin, O., Zhbanova, K. S., Alkouri, H. P. Z., \& Rule, A. C. 2013. Pop-Up Constructions Motivate and Reinforce Science Learning for Upper Elementary Students. Journal of Science Activities, 50:119-133

Brabrand, C. \& Dahl, B. 2015. Using the SOLO Taxonomy to Analyze Competence Progression of University Science Curricula. Journal of Science Crricula, 1-18 Klein, J.L., Gray, P., Zhbanova, K. S., \& Rule, A. C. 2015. Upper Elementary Students Creatively Learn Scientific Features of Animal Skulls by Making Movable Books. Journal for Learning through The Arts, 11(1):1-32

Kuswana, W. S. 2012. Taksonomi Kognitif. Bandung: Remaja Rosdakarya

Nur, M. 2010. Strategi-strategi Belajar. Surabaya: UNESA-Press

Potter, M. K., \& Kustra, E. 2012. A Primer Learning Outcomes and the SOLO Taxonomy. Procedia Course Design for Constructive Aligment. Centre Teaching and Learning, University of Windsor.

Restiadi, T. P. 2013. Upaya Menumbuhkan Sikap Tanggap Bencana Tsunami Melalui Pembelajaran Bervisi SETS IPA Kelas V Sekolah Dasar. Journal of Primary $\begin{array}{llll}\text { Educational } & 2 & \text { (2) } & 2013 .\end{array}$ http://journal.unnes.ac.id/sju/index.php/jpe. Diakses tanggal 31 Oktober 2016Sanjaya, W. 2006. Strategi Pembelajaran Berorientasi Standar Proses Pendidikan Edisi Pertama. Jakarta: Kencana Prenadamedia Group

Santrock, J. W. 2008. Psikologi Pendidikan (Tri Wibowo B. S., Trans). Jakarta: Kencana Prenada Media Group

Small, M. Y. 1996. Cognitive Development. New York: Harcourt Brace Jovanovich.

Suryanti, Isnawati, Sukartiningsih, W., dan Yulianto, B. 2008. Model-model Pembelajaran Inovatif. Surabaya: Unesa University Press (Anggota IKAPI)

Suyono dan Harianto. 2011. Belajar dan Pembelajaran Teori dan Konsep Dasar. Bandung: Remaja Rosdakarya

Wena, M. 2012. Strategi Pembelajaran Inovatif Kontemporer Suatu Tinjauan Konseptual Operasional . Jakarta: Bumi Aksara

Widoyoko, S. E. P. 2011. Teknik Penyusunan Instrumen Penelitian. Yogyakarta: Pustaka Pelajar 